\title{
Sexting: Emotional promiscuity and sexual sensation seeking in Pakistani young adults
}

\author{
Ahmed Bilal* \\ Department of Applied Psychology, The Islamia University of Bahawalpur, Bahawalpur, Pakistan. \\ * Correspondence Emails: ahmad.bilal@iub.edu.pk|ahmadbilal4@gmail.com
}

\begin{abstract}
The previous studies found sexting to be an established phenomenon in young adults. This study is aimed to predict sexting from emotional promiscuity and sexual sensation seeking in young adults and to assess the role of age and sex in relationship among sexting, emotional promiscuity, and sexual sensation seeking. 201 undergraduate students of both sexes are recruited from the main campus of The Islamia University of Bahawalpur with age range of 18-30 years. Three scales Brief Sexting Scale, Emotional Promiscuity Scale and Sexual Sensation Seeking Scale are administered to collect the data. All the participants were required to sign the essential informed consent before participation. The data were analyzed by Statistical Package for the Social Sciences (SPSS), version 25. There has been found a statistically significant positive relationship among sexting, emotional promiscuity and sexual sensation seeking. The sexual sensation seeking significantly predicted sexting. The women are found significantly higher on sexting and sexual sensation seeking. There has been found no age differences in sexting, emotional promiscuity and sexual sensation seeking. It has been concluded that the sexual sensation seeking significantly predicted sexting in university students.
\end{abstract}

Article History

Received:

October 22, 2020

Last Revised:

April 8, 2021

Accepted:

April 9, 2021

Published:

April 17, 2021

Keywords: sexting, emotional promiscuity, sexual sensation seeking, young adults, adolescence, Pakistani youth, Pakistani adults.

\section{How to Cite:}

Bilal, A. (2021). Sexting: Emotional promiscuity and sexual sensation seeking in Pakistani young adults. Liberal Arts and Social Sciences International Journal (LASSIJ), 5(1), 75-88. https://doi.org/10.47264/idea.lassij/5.1.6

\section{Publisher's Note:}

IDEA PUBLISHERS (IDEA Journals Group) stands neutral with regard to the jurisdictional claims in the published maps and the institutional affiliations.

Copyright: ( 2021 The Author(s), published by IDEA PUBLISHERS (IDEA Journals Group). This is an Open Access article published under the Creative Commons Attribution-NonCommercial 4.0 International License (http://creativecommons.org/licenses/by-nc/4.0/) 


\section{Introduction}

Sexting has turned out to be an integral part of young people's lives in an age of globalization (Dodaj et al., 2020). The exact prevalence of sexting in Pakistani young adults is not known due to lack of research in non-Western countries (Ngo et al., 2017) and sensitivity of the problem. Yet, some previous studies pointed toward the role of promiscuity and sexual sensation seeking as the causes of sexting in young adults in Pakistan (Anwar et al., 2019). However, there is currently lack of studies on relationship of sexual sensation seeking and promiscuity with sexting (Jones \& Paulhus, 2012) as previously found researches had mostly been conducted in western context (Brar et al., 2018). The present study was aimed at finding out the relationship of sexual sensation seeking and promiscuity with sexting in young Pakistani adults. The study also aimed to find out age and gender differences across sexual sensation seeking, promiscuity, and sexting in young adults.

In recent times, the adult romantic relationships had been mediated by computer or technology based sexual communication. This is now popularly called sexting (Morelli et al., 2016; Drouin et al., 2013). Currently, the text messaging and social networking sites are popular among young adults of age 18-29 years (Smith, 2011; Hampton et al., 2011). Young adulthood is a period starting with the age of 18 years and ending with 29 years (Arnett et al., 2014). Almost, $95 \%$ of young adults in this age group own a cell phone. Among those, who own cell phone, 97\% send or receive text messages. A study by Brenner and Smith (2013) revealed that 90\% of the internet users between the ages of 18-29 years use social networking sites regularly. These platforms have also become the trends to be used for sending or receiving sex related content (Lenhart, 2009). The text messaging is the popular method of sexting followed by email, Facebook, and Twitter (Drouin et al., 2013).

The term sexting was used as an official word in 2009 initially by media (Forbs, 2011). The studies on sexting are growing after the results were published from the famous Sex and Tech Survey conducted in 2008 (Döring, 2014; Temple \& Lu, 2018). The scientific community is divided around the legitimacy of sexting behaviour among adolescents. Some consider sexting a normal behaviour while others consider sexting a negative behaviour (Döring, 2014). The research, on the other hand, supports the later (Kosenko et al., 2017).

As the researchers have no uniform definition of sexting, therefore, the prevalence of sexting can not be determined despite several studies reported different prevalence rates (Strassberg et al., 2013; Drouin et al., 2013). However, sexting is a popular behaviour among adolescents and young adults (Peskin et al., 2013). The prevalence of sexting a photo in young adults of ages $18-30$ years was found to be $33 \%$ and $57 \%$ respectively (Klettke et al., 2014). Previously, the Sex and Technology Survey indicated the prevalence of sexting from 20-38\% in teenagers (13-19 years) and 33-58\% in young adults of ages 20-26 years (The National Campaign, 2008).

The prevalence of sexting depends on the definition of sexting that what is being included in sexting behaviour and how it is being carried out (Dir et al., 2013; Drouin et al., 2013). However, when defined explicitly as sending or receiving naked or semi naked photos or videos, 13-44 \% of young adults have been found to sext (Benotsch et al., 2013; GordonMesser et al., 2013). The seminal study by Lenhart (2009) defined sexting as sending semi naked or naked, sexually suggestive photos or videos of one's self. Later, Weisskirch and Delevi (2011) broadened the definition of sexting by including the sending or receiving of semi naked or naked messages of one's self. 
However, researchers have no agreement on the substance of sexts, the method or device used to send such sexts, and the context of the relationship in which the sexting occurs (Drouin et al., 2013). The previous research founded that sexts were sexually explicit and suggestive, naked, or semi-naked; the method of sexting was sending or receiving text and instant messages, and use of social networking sites; and sexting occurred in the contexts of relationship with romantic and committed partners, or cheating partners (Drouin \& Landgraff, 2012). The commonest method of sexting was through the use of internet and cell phones (Gamez-Guadix et al., 2017).

There is currently lack of studies on relationship of sexual sensation seeking and promiscuity with sexting (Jones \& Paulhus, 2012). The previously found researches had been conducted in western context. The present study aimed at finding out the relationship of sexual sensation seeking and promiscuity with sexting in young Pakistani adults. The study also aimed to find out age and gender differences across sexual sensation seeking, promiscuity, and sexting in young adults.

\section{Review of literature}

The sexting is associated with both promiscuity and sexual sensation seeking behaviour (i.e., the tendency to seek sexually seductive and innovative behaviours including sexually risky behaviour) as found by a meta analysis (Mori et al., 2019; Kosenko et al., 2017). Several reasons have been offered in the past for engaging in sexting and sexual sensation seeking behaviour of the individuals. One is to consider sexting as an alternative to physical sexual relationship (Lenhart, 2009).

The sexual sensation seeking behaviour had been found to be high in sexters as compared to non sexters and is considered by some to be the predictor of sexting (Champion \& Pedersen, 2015; Van-Ouytsel et al., 2014; Dir et al., 2013). Moreover, the sexting is found to be associated with promiscuity too. The young adults who engaged in sexting behaviours were found more likely to engage in casual sex including sex with multiple partners, a form of emotional and sexual promiscuity (Dake et al., 2012; Rice et al., 2014).

The phenomenon of promiscuity is correlated with lowered quality of healthy living (Okafor \& Duru, 2010). The phenomenon of promiscuity can be defined as the tendency to engage in some form of emotional or sexual relationship with multiple partners, and have casual sex (Jones \& Paulhus, 2012). The promiscuity can either be emotional or sexual, the sexual promiscuity includes the forms such as casual sex and hook-ups (Garcia et al., 2010), and the emotional promiscuity includes falling in love easily with multiple partners (Jones \& Paulhus, 2012). It has been found that sexual promiscuity leads to the experience of emotional promiscuity as well (Pinto \& Arantes, 2017; Jones \& Paulhus, 2012).

The older participants were found more likely to be engaged in sexting behaviour as reported by a number of researches (Ybarra \& Mitchell, 2014; Rice et al., 2014; Baumgartner et al., 2014). Although, the older adults were found to be involved in sexting behaviours, yet the sexting behaviour had adverse effects on teenagers (Livingstone \& Gorzig, 2014).

There is inconsistency in previous literature regarding the gender wise prevalence of sexting. Most studies found no gender differences in sexting behaviour (Benotsch et al., 2013; Weisskirch \& Delevi, 2011), while some other studies found men to send and receive more 
sext as compared to women (Sharma et al., 2019; Strassberg et al., 2013; Gámez-Guadix et al., 2015). Alternatively, there are studies which document the prevalence of sexting in women is high as compared to men (Reyns et al., 2013). There are gender differences in sexual sensation seeking and promiscuity too. Another study found that men were more likely to engage in sexual promiscuity whereas women were more likely to engage in emotional promiscuity (Sagarin et al., 2003). Similarly, the men had been found to be high in sexual sensation seeking as compared to women (Flanders et al., 2013).

\section{Research methodology}

\subsection{Research design}

The cross sectional and survey research design was employed in this research.

\subsection{Participants}

201 undergraduate and postgraduate students of both sexes $(M=100, W=101)$ were recruited purposively from the main campus of The Islamia University of Bahawalpur in South Punjab, Pakistan based on their Yes response to sexting question. The sample size was calculated by referring to online available sample size calculator available at fluidsurveys.com. The estimated sample size was 375 with 95\% confidence interval and 5\% margin of error. The response rate of participants was around 54\%. The students of age group 18 to 30 years $(\mathrm{M}=21.63, \mathrm{SD}=2.42)$ were included in the sample. All the participants signed the essential written informed consent before enrolling for the study.

\subsection{Inclusion and exclusion criteria}

The students studying in The Islamia University of Bahawalpur who were under the age of 30 years and who responded yes to $1^{\text {st }}$ question on Brief Sexting Scale were included in the study. The students of other institutions and beyond 30 years or those responded no to $1^{\text {st }}$ question on Brief Sexting Scale were excluded from the study.

\subsection{Measures}

\subsubsection{Informed Consent Form (ICF)}

The researchers explaining the nature of the study to participants developed an informed consent form. All the participants were required to read and agree to the informed consent form before enrolling for the study. All ethics related information and research protocols were explained to the participants before their enrolment.

\subsubsection{Socio-Demographic Information Form (SDIF)}

A socio-demographic information form was constructed by the researcher that contained information about the age and sex of the participants.

\subsubsection{Brief Sexting Scale (BSS)}

The six items were adapted from the Sexting Behaviours Questionnaire (Dir, 2012) designed 
in a Likert-type scale from 1-5 where 1 represented never and 5 represented frequently. The internal consistency of the scale was found to be 0.81 Cronbach Alpha.

\subsubsection{Emotional Promiscuity Scale (EPS)}

The Emotional Promiscuity Scale (EPS) was developed by Jones (2011) which contains 10 items designed in Likert-type format from 1 to 5 where 1 represented strongly disagree and 5 represented strongly agree. The scale measured the tendency of emotional promiscuity in university students of both sexes. The internal consistency of the scale was 0.69 Cronbach Alpha for both sexes.

\subsubsection{Sexual Sensation Seeking Scale (SSSS)}

The Sexual Sensation Seeking Scale (SSSS) was developed by Kalichman \& Rompa (1995) to assess the constructs of sexual adventure and sexual risk-taking behaviours in adolescents and adults. The scale has a total of 10 items designed in Likert type format from 1 to 4 . The 1 represents not at all like me and 4 represents very much like me and total score is the sum of score on each item. The scale has internal consistency of 0.83 and 0.81 Cronbach Alpha for male and female college students respectively.

\subsection{Procedure}

The Research Ethics Committee of the department of Applied Psychology at The Islamia University of Bahawalpur, Pakistan granted ethical approval for conducting the study. The data collection was duly allowed by the Head of Department of Applied Psychology at The Islamia University of Bahawalpur. All the participating men and women signed the written informed consent before enrolment in the study. The data was collected from the undergraduate and postgraduate students from the main campus of The Islamia University of Bahawalpur by administering the SDIF and the 3 scales.

\subsection{Ethical considerations}

The study met all the ethical considerations of research. The nature and purpose of the study including possible harms was explained to all participating students and written informed consent was obtained from all the participating students before enrolling them in the study. They were ensured about the confidentiality of their data.

\subsection{Statistical analysis}

The Statistical Package for the Social Sciences (IBM, USA) version 25 was used to analyze the data. The results were expressed in the form of socio-demographic characteristics of participants at baseline, correlation among the sexting, emotional promiscuity and sexual sensation seeking, regression analysis with sexting as outcome variable, and several t tests for finding age and sex differences in all three variables. The effect size in t tests was represented by Cohen's d. The 0.2, 0.5, and 0.8 were considered small, medium and large effect sizes respectively (Cohen, 1977). The correlation was two tailed and was significant at 99\% confidence interval whereas the regression analysis and tests were significant at $95 \%$ confidence interval. 


\subsection{Limitations}

A small, university based sample size is the limitation of this study, as findings cannot be generalized to broader university sample. The purposive nature of the sexting scale and cultural sensitivity associated with the phenomena of sexting made it difficult for people to take part in the survey. Other socio demographic variables should have been included to make the research more informative.

\section{Results and analysis}

\subsection{Baseline characteristics of participants}

The socio-demographic characteristics of the participants at baseline are outlined in table- 1 . The $(n=201)$ undergraduate and postgraduate students participated in the study. Around $88 \%$ of them was in the age range of 18-24 years whereas $12 \%$ were in the age range of 25-30 years $(\mathrm{M}=21.63$ years; $\mathrm{SD}=2.42)$. There were $100(49.8 \%)$ men while $101(50.2 \%)$ were women students.

Table-1: Socio-demographic characteristics of participants at baseline

\begin{tabular}{llll}
\hline Socio-Demographic Variables & Baseline Characteristics & $\mathrm{n}$ & $\%$ \\
\hline \multirow{2}{*}{ Age } & $18-24$ years & 176 & 87.6 \\
$(\mathrm{M}=21.63, \mathrm{SD}=2.42)$ & $25-30$ years & 25 & 12.4 \\
& Total & 201 & 100.0 \\
\hline \multirow{3}{*}{ Sex } & Men & 100 & 49.8 \\
& Women & 101 & 50.2 \\
& Total & 201 & 100.0 \\
\hline
\end{tabular}

\subsection{Correlation analysis}

The table- 2 shows the results of correlation analysis among sexting, emotional promiscuity, and sexual sensation seeking in the participating students. There was found a significant positive correlation of the sexting with both the emotional promiscuity $(\mathrm{r}(199)=.33, \mathrm{p}<.01)$ and the sexual sensation seeking $(\mathrm{r}(199)=.53, \mathrm{p}<.01)$. Similarly, there was also a significant positive correlation between the emotional promiscuity and the sexual sensation seeking $(\mathrm{r}(199)=.50$, $\mathrm{p}<.01)$.

Table-2: Correlations among sexting, emotional promiscuity and sexual sensation seeking

\begin{tabular}{lllllll}
\hline Variables & $\mathrm{n}$ & $\mathrm{M}$ & $\mathrm{SD}$ & 1 & 2 & 3 \\
\hline Sexting & 201 & 14.62 & 10.58 & - & & \\
$\begin{array}{l}\text { Emotional } \\
\text { Promiscuity }\end{array}$ & 201 & 26.06 & 8.67 & $.33^{* *}$ & - & \\
$\begin{array}{l}\text { Sexual } \\
\begin{array}{l}\text { Sensation } \\
\text { Seeking }\end{array}\end{array}$ & 201 & 22.67 & 9.21 & $.53^{* *}$ & $.50^{* *}$ & - \\
\hline
\end{tabular}
$* * p<.01$

\subsection{Multiple regression analysis}

The Table 3 gives the regression analysis to predict the sexting from emotional promiscuity 
and sexual sensation seeking. The multiple linear regression significantly predicted sexting $\left(\mathrm{F}(2,198)=41.09, \mathrm{p}<.05, \mathrm{R}^{2}=.29\right)$. The emotional promiscuity did not significantly predict the sexting $(\mathrm{t}=1.34, \mathrm{p}>.05)$ whereas the sexual sensation seeking did significantly predict sexting $(\mathrm{t}=7.08, \mathrm{p}<.05)$, although the overall model was significant.

Table-3: Multiple regression analysis

\begin{tabular}{|c|c|c|c|c|c|c|c|}
\hline Predictors & $\mathrm{R}^{2}$ & $\mathrm{~F}(\mathrm{df})$ & Sig. & $\beta$ & SE & $\mathrm{t}$ & Sig. \\
\hline $\begin{array}{l}\text { Emotional } \\
\text { Promiscuity }\end{array}$ & & & & .11 & .08 & 1.34 & .18 \\
\hline $\begin{array}{l}\text { Sexual } \\
\text { Sensation } \\
\text { Seeking }\end{array}$ & .29 & $\begin{array}{l}41.09 \\
(2,198)\end{array}$ & .000 & .56 & .07 & 7.08 & .000 \\
\hline
\end{tabular}

Outcome=Sexting

\section{4. $\quad t$ Tests}

The Table 4 gives the results of $\mathrm{t}$ tests computed to find differences in socio-demographic variables such as age, and sex for sexting, emotional promiscuity, and sexual sensation seeking. There were no statistically significant differences in sexting $(M=14.30, S D=10.80$ vs $M=16.88$, $\mathrm{SD}=8.72)$, emotional promiscuity $(\mathrm{M}=25.99, \mathrm{SD}=8.82$ vs $\mathrm{M}=26.56, \mathrm{SD}=7.70)$, and sexual sensation seeking $(\mathrm{M}=22.23, \mathrm{SD}=9.26$ vs $\mathrm{M}=25.80, \mathrm{SD}=8.33)$ between the two age groups respectively $(\mathrm{t}(199)=-1.14, \mathrm{p}=.25$, Cohen'd $=.26) ;(\mathrm{t}(199)=-.30, \mathrm{p}=.76$, Cohen's $\mathrm{d}=.06)$; and $(\mathrm{t}(199)=-1.82, \mathrm{p}=.07$, Cohen's $\mathrm{d}=.40)$. There was found statistically significant differences between sexes in sexting and sexual sensation seeking respectively $(\mathrm{t}(199)=-4.57, \mathrm{p}=.000$, Cohen's $\mathrm{d}=.64$; and $(\mathrm{t}(199)=-2.84, \mathrm{p}=.005$, Cohen's $\mathrm{d}=.40)$. The women were found significantly higher on sexting $(M=17.86, S D=10.67$ vs $M=11.35, S D=9.47)$ and sexual sensation seeking $(M=24.48, S D=9.57$ vs $M=20.85, S D=8.49)$ as compared to men respectively. There was no significant gender difference $(\mathrm{M}=26.05, \mathrm{SD}=7.82$ vs $\mathrm{M}=26.07$, $\mathrm{SD}=9.48)$ in emotional promiscuity $(\mathrm{t}(199)=-.02, \mathrm{p}=.98$, Cohen's $\mathrm{d}=.002)$.

Table-4: Results of several $t$ tests

\begin{tabular}{llllllll}
\hline Age & $18-24 y(n=176)$ & $25-30 y$ & $(\mathrm{n}=25)$ & & & \\
\hline Variables & $\mathrm{M}$ & $\mathrm{SD}$ & $\mathrm{M}$ & $\mathrm{SD}$ & $t(\mathrm{df})$ & $p$ & Cohen's d \\
\hline Sexting & 14.30 & 10.80 & 16.88 & 8.72 & $-1.14(199)$ & .25 & .26 \\
Emotional Promiscuity & 25.99 & 8.82 & 26.56 & 7.70 & $-.30(199)$ & .76 & .06 \\
Sexual Sensation Seeking & 22.23 & 9.26 & 25.80 & 8.33 & $-1.82(199)$ & .07 & .40 \\
\hline Sex & $\mathrm{M}(\mathrm{n}=100)$ & $\mathrm{W}(\mathrm{n}=101)$ & & & \\
\hline Variables & $\mathrm{M}$ & $\mathrm{SD}$ & $\mathrm{M}$ & $\mathrm{SD}$ & $t(\mathrm{df})$ & $p$ & Cohen's d \\
\hline Sexting & 11.35 & 9.47 & 17.86 & 10.67 & $-4.57(199)$ & .000 & .64 \\
Emotional Promiscuity & 26.05 & 7.82 & 26.07 & 9.48 & $-.02(199)$ & .98 & .002 \\
Sexual Sensation Seeking & 20.85 & 8.49 & 24.48 & 9.57 & $-2.84(199)$ & .005 & .40 \\
\hline
\end{tabular}

\section{Discussion and findings}

The present study was aimed at finding a relationship among sexting, emotional promiscuity, and sexual sensation seeking and to find age and sex differences in these behaviours among university students. The present study did find a significant positive relationship among the sexting, emotional promiscuity, and sexual sensation seeking. The previous studies reported a significant relationship between emotional promiscuity, sexual sensation seeking, and sexting (Mori et al., 2019; Kosenko et al., 2017). Similarly, there was also a significant positive 
relationship between emotional promiscuity and sexual sensation seeking in participants. The previous studies did report a significant correlation between sexual sensation seeking and emotional promiscuity (Kosenko et al., 2017).

The multiple regression analysis reported that sexual sensation seeking significantly predicted sexting in university students. The previous research reported that sexual sensation seeking led to the behavioural expression of sexting in adolescents and young adults (Champion \& Pedersen, 2015; Van-Ouytsel et al., 2014; Dir et al., 2013). The present study confirmed the previous findings in Pakistani university students too. However, the present study found that emotional promiscuity did not predict the sexting behaviour, although, there was a positive association between the two behaviours.

The present study did not report a significant difference in two age groups of young adults (1824 years and 25-30 years) in sexting, emotional promiscuity, and sexual sensation seeking. The previous research did indicate that increased age was positively associated with sexting and emotional promiscuity, and the sexual behaviour increased with age (Ybarra \& Mitchell, 2014; Rice et al., 2014; Baumgartner et al., 2014). But this pattern was not found in this study. The sensitive nature of these issues (emotional promiscuity and sexting) made it difficult to be reported by this study sample. The university students may have shown the social desirability effect and have not revealed truly their experiences.

There were, on the other hand, significant gender differences found in the sexting and sexual sensation seeking. The women students were found to send or receive more sexts and show more sexual sensation seeking as compared to the men. The previous research about the gender differences in the sexting is mixed, although, some studies did report the women to be higher in the sexting (Reyns et al., 2013). Given the cultural context of Pakistan, the finding of the women being high on sexual sensation seeking is new and warrants further research. The overall repressive attitude towards these behaviours is the one reason that the women expressed their experiences more openly. The present study did not find any gender difference in the emotional promiscuity.

\subsection{Conclusion}

The present research concludes that sexting is associated with emotional promiscuity and sexual sensation seeking in young adults, though, sexual sensation seeking was found to be strong predictor of sexting in young adults. The women students were found high in sexting and sexual sensation seeking as compared to men students. There should be relevant education at campus level so that young adults may make informed choices about engaging in these behaviours (Sharma et al., 2019). The further research may be conducted with other socio demographic variables in context of sexting in young adults.

\subsection{Recommendations}

The findings recommend providing education about these behaviours as a part of university curriculum although, simply providing education for teaching young people to avoid sexting is not sufficient and does not yield positive results (Walker et al., 2013). Yet, education can make young people take more informed decisions. 


\section{Funding}

The author did not receive any funding for conducting or reporting of this research.

\section{Conflict of interest}

The author declare no conflict of interest.

\section{References}

Anwar, N., Saleem, M., Siddique, A. R., Akhtar, F., \& Durrani, A. K. (2019). Exploring causes and triggers of sexting among university students: A qualitative conceptualization in focus. Journal of Research and Reviews in Social Sciences Pakistan, 2(2), 541-549. http://journal.kinnaird.edu.pk/wp-content/uploads/2018/03/14.pdf

Arnett, J. J., Źukauskienè, R., \& Sugimura, K. (2014). The new life stage of emerging adulthood at ages 18-29 years: Implications for mental health. Lancet Psychiatry, 1(7), 569-576. https://doi.org/10.1016/S2215-0366(14)00080-7

Baumgartner, S. E., Sumter, S. R., Peter, J., Valkenburg, P. M., \& Livingstone, S. (2014). Does country context matter? Investigating the predictors of teen sexting across Europe. Computers in Human Behaviour, 34, 157-164. https://doi.org/10.1016/j.chb.2014.01.041

Benotsch, E. G., Snipes, D. J., Martin, A. M., \& Bull, S. S. (2013). Sexting, substance use, and sexual risk behaviour in young adults. The Journal of adolescent health: official publication of the Society for Adolescent Medicine, 52(3), 307-313. https://doi.org/10.1016/j.jadohealth.2012.06.011

Brar, P., Dworkin, J., \& Jang, J. (2018). Association of parenting with sexual attitudes and behaviours of college students in India. Sexuality and Culture, 22 (4), 1037-1053. https://doi.org/10.1007/s12119-018-9511-9

Brenner, J., \& Smith, A. (2013). 72\% of online adults are social networking site users: Social networking sites remain most popular among young adults, but other age groups continue to increase their engagement. Pew Internet and American Life Project. http://pewinternet.org/Reports/2013/social-networking-sites.aspx

Champion, A. R., \& Pedersen, C. L. (2015). Investigating differences between sexters and nonsexters on attitudes, subjective norms, and risky sexual behaviours. The Canadian Journal of Human Sexuality, 24(3), 205-14. https://doi.org/10.3138/cjhs.243-A5

Cohen J. (1977). Statistical power analysis for the behavioural sciences (Revised edition). Lawrence Erlbaum Associates. http://www.utstat.toronto.edu/ brunner/oldclass/378f16/readings/CohenPower.pdf

Dake, J. A., Price, J. H., Maziarz, L., \& Ward, B. (2012). Prevalence and correlates of sexting behaviour in adolescents. American Journal of Sexuality Education, 7(1), 1-15. https://doi.org/10.1080/15546128.2012.650959

Dir, A. L. (2012). Understanding sexting behaviours, sexting expectancies, and the role of sensation seeking in sexting behaviours (Master's thesis, Purdue University). https://scholarworks.iupui.edu/bitstream/handle/1805/3358/defence\%20manuscript \%20formatted\%20final.pdf?sequence $=3$

Dir, A. L., Cyders, M. A., \& Coskunpinar, A. (2013). From the bar to the bed via mobile phone: A first test of the role of problematic alcohol use, sexting, and impulsivity-related 
traits in sexual hook-ups. Computers in Human Behaviour, 29(4), 1664-1670. http://dx.doi.org/10.1016/j.chb.2013.01.039

Dodaj, A., Sesar, K., \& Jerinic, S. (2020). A Prospective Study of High-School Adolescent Sexting Behaviour and Psychological Distress. The Journal of Psychology, 154(2), 111-128. https://doi.org/10.1080/00223980.2019.1666788

Doring, N. (2014). Consensual sexting among adolescents: Risk prevention through abstinence education or safer sexting? Journal of Psychosocial Research on Cyberspace, 8(1), article 9. http://doi.org/10.5817/CP2014-1-9

Drouin, M., \& Landgraff, C. (2012). Texting, sexting, attachment, and intimacy in college students' romantic relationships. Computers in Human Behaviour, 28(2), 444-449. http://dx.doi.org/10.1016/j.chb.2011.10.015

Drouin, M., Vogel, K.N., Surbey, A., \& Stills, J.R. (2013). Let's talk about sexting, baby: Computer-mediated sexual behaviours among young adults. Computers in Human Behaviour, 29(5), 25-30. http://dx.doi.org/10.1016/j.chb.2012.12.030

Flanders, C. E., Arakawa, D. R., \& Cardozo, A. C. (2013). Positive Implications for Sexual Sensation Seeking: An Exploratory Study. Electronic Journal of Human Sexuality, 16, n.p. http://www.ejhs.org/volume16/Sensation.html

Forbs, G. S. (2011). Sex, cells, and Sorna. William Mary Law Review, 52(5), 1717-1746. https://scholarship.law.wm.edu/cgi/viewcontent.cgi?article=3388\&context=wmlr

Gamez-Guadix, M., Almendros, C., Borrajo, E., \& Calvete, E. (2015). Prevalence and association of sexting and online sexual victimization among Spanish adults. Sexuality Research and Social Policy, 12 (2), 145154. https://doi.org/10.1007/s13178-015-0186-9

Gamez-Guadix, M., de-Santisteban, P., \& Resett, S. (2017). Sexting among Spanish adolescents: Prevalence and personality profiles. Psicothema, 29(1), 29-34. https://www.redalyc.org/pdf/727/72749498004.pdf

Garcia, J. R., MacKillop, J., Aller, E. L, Merriwether, A. M., Wilson, D. S., \& Lum, J. K. (2010). Associations between dopamine D4 receptor gene variation with both infidelity and sexual promiscuity. PLOS One, 5(11). e14162. https://doi.org/10.1371/journal.pone.0014162

Gordon-Messer, D., Bauermeister, J.A., Grodzinski, A., \& Zimmerman, M. (2013). Sexting among young adults. The Journal of Adolescent Health, 52(3), 301-306. http://dx.doi.org/10.1016/j.jadohealth.2012.05.013

Hampton, K. N., Goulet, L. S., Rainie, L., \& Purcell, K. (2011). Social networking sites and our lives: How people's trust, personal relationships, and civic and political involvement are connected to their use of social networking sites and other technologies. Pew Internet \& American Life Project. http://www.pewinternet.org/Reports/2011/Technology-and-socialnetworks.aspx

Jones, D. (2011). The emotional promiscuity scale. In: T. D. Fisher, C. M. Davis, W. L. Yarber, \& S. L. Davis (Eds.), Handbook of Sexuality Related Measures (3rd ed.), pp. 226227. Routledge.

Jones, D. N., \& Paulhus, D. L. (2012). The role of emotional promiscuity in unprotected sex. $\begin{array}{lllll}\text { Psychology } \quad \& \quad \text { health } & \text { 27(9), }\end{array}$ https://doi.org/10.1080/08870446.2011.647819

Kalichman, S. C., \& Rompa, D. (1995). Sexual sensation seeking and sexual compulsivity scales: Reliability, validity, and predicting HIV risk behaviour. Journal of Personality Assessment, 65 (3), 586-601. https://doi.org/10.1207/s15327752jpa6503_16 
Klettke, B., Hallford, D. J., \& Mellor, D. J. (2014). Sexting prevalence and correlates: a systematic literature review. Clinical Psychology Review, 34(1), 44-53. https://doi.org/10.1016/j.cpr.2013.10.007

Kosenko, K., Luurs, G., \& Binder, A. R. (2017). Sexting and sexual behaviour 2011-2015: A critical review and meta-analysis of a growing literature. Journal of Computer Mediated Communication, 22 (3), 141-160. https://doi.org/10.1111/jcc4.12187

Lenhart, A. (2009). Teens and sexting: How and why minor teens are sending sexually suggestive nude or nearly nude images via text messaging. Pew Internet \& American Life Project. http://www.pewinternet.org/Reports/2009/Teens-and-Sexting.aspx

Livingstone, S., \& Gorzig, A. (2014). When adolescents receive sexual messages on the internet: Explaining experiences of risk and harm. Computers in Human Behaviour, 33, 8-15. http://doi.org/10.1016/j.chb.2013.12.021

Morelli, M., Bianchi, D., Baiocco, R., Pezzuti, L., \& Chirumbolo, A. (2016). Sexting, psychological distress and dating violence among adolescents and young adults. $\begin{array}{llll}\text { Psicothema, } & 28 & \text { (2), 137-142. }\end{array}$ https://reunido.uniovi.es/index.php/PST/article/view/11169/10485

Mori, C., Temple, J. R., Browne, D., \& Madigan, S. (2019). Association of Sexting with Sexual Behaviours and Mental Health Among Adolescents: A Systematic Review and Metaanalysis. Journal of American Medical Association Pediatrics, 173 (8), 770-779. https://doi.org/10.1001/jamapediatrics.2019.1658

Ngo, F., Jaishankar, K., \& Agustina, J. R. (2017). Sexting: Current research gaps and legislative issues. International Journal of Cyber Criminology, 11(2), 161-168. https://doi.org/10.5281/zenodo.1037369

Okafor, H. C., \& Duru, N. E. (2010). Sexual promiscuity among female undergraduates in tertiary institutions in imo state: An issue for healthy living. Edo Journal of Counselling, 3(1), 100-109. https://doi.org/10.4314/ejc.v3i1.52687

Peskin, F. M., Markham, C. M., Addy, R. C., Shegog, R., Thiel, M., \& Tortolero, S. R. (2013). Prevalence and patterns of sexting among ethnic minority urban high school students. Cyberpsychology, Behaviour and Social Networking, 16(6), 454-459. https://doi.org/10.1089/cyber.2012.0452

Pinto, R., \& Arantes, J. (2017). The Relationship between Sexual and Emotional Promiscuity and Infidelity. Athens Journal of Social Sciences, 4(4), 385-398. https://doi.org/10.30958/ajss.4-4-3

Reyns, B. W., Burek, M. W., Henson, B., \& Fisher, B. S. (2013). The unintended consequences of digital technology: Exploring the relationship between sexting and cyber victimization. Journal of Crime and Justice, 36(1), 1-17. https://doi.org/10.1080/0735648X.2011.641816

Rice, E., Gibbs, J., Winetrobe, H., Rhoades, H., Plant, A., Montoya, J., \& Kordic, T. (2014). Sexting and sexual behaviour among middle school students. Pediatrics, 134(1), 2128. https://doi.org/10.1542/peds.2013-2991

Sagarin, B. J., Becker, D. V., Guadagno, R. E., Nicastle, L. D., Millevoi, A. (2003). Sex differences (and similarities) in jealousy: The moderating influence of infidelity experience and sexual orientation of the infidelity. Evolution and Human Behaviour 24(1), 17- 23. https://doi.org/10.1016/S1090-5138(02)00106-X

Sharma, M. K., Marimuthu, P., Anand, N., N, S., P, T., Thakur, P. C., Singh, P., \& Gupta, H. (2019). Sexting and Self-Esteem Among Youth: Preliminary Trend for Building Cyberliteracy. Journal of Psychosexual Health, 1(3-4), 271274. https://doi.org/10.1177/2631831819890768 
Smith, A. (2011). Americans and text messaging. Pew Internet and American Life Project. http://pewinternet.org/ /media//Files/Reports/2011/Americans\%20and\%20Text\%20 Messaging

Strassberg, D. S., McKinnon, R. K., Sustaita, M. A., \& Rullo, J. (2013). Sexting by high school students: An exploratory and descriptive study. Archives of Sexual Behaviour, 42(1), 15-21. http://dx.doi.org/10.1007/s10508-012-9969-8.

Temple, J. R., \& Lu, Y. (2018). Sexting from a Health Perspective: Sexting, Health, and Risky Sexual Behaviour. In M. Walrave., J. van Ouytsel., K. Ponnet., J. R. Temple (Eds.), Sexting (1st ed., pp. 53-61). Palgrave Macmillan.

The National Campaign. (2008). Sex and Tech: results from a survey of teens and young adults. National Campaign to Prevent Teen and Unplanned Pregnancy. https://www.dibbleinstitute.org/pdf/SexTech_Summary.pdf

Van-Ouytsel, J., Van Gool, E., Ponnet, K., \& Walrave, M. (2014). Brief report: The association between adolescents' characteristics and engagement in sexting. Journal of Adolescence, 37(8), 1387-1391. https://doi.org/10.1016/j.adolescence.2014.10.004

Walker, S., Sanci, L., \& Temple-Smith, M. (2013). Sexting: Young women's and men's views on its nature and origins. Journal of Adolescent Health, 52(6), 697-701. https://doi.org/10.1016/j.jadohealth.2013.01.026

Weisskirch, R. S., \& Delevi, R. (2011). 'Sexting' and adult romantic attachment. Computers in Human Behaviour, 27(5), 1697-1701. http://dx.doi.org/10.1016/j.chb.2011.02.008

Ybarra, M. L., \& Mitchell, K. J. (2014). Sexting and its relation to sexual activity and sexual risk behaviour in a national survey of adolescents. Journal of Adolescent Health, 55(6), 757-764. https://doi.org/10.1016/j.jadohealth.2014.07.012 
Annexure-A:

1. Socio-demographic Information Form (SDIF):

a) Name (optional):

b) Sex:

c) Age:

2. Brief Sexting Scale (BSS)

\begin{tabular}{|l|l|l|l|l|l|l|l|}
\hline $\begin{array}{l}\text { Sr. } \\
\#\end{array}$ & Statements & Never & $\begin{array}{l}\text { Only Once } \\
\text { / Twice }\end{array}$ & $\begin{array}{l}\text { Less than } \\
\text { Monthly }\end{array}$ & Monthly & Weekly & Daily \\
\hline 1 & $\begin{array}{l}\text { Have you ever sent sexually } \\
\text { suggestive photo or video of } \\
\text { yourself? }\end{array}$ & $\begin{array}{l}\text { Have you ever sent a photo or } \\
\text { video of yourself in underwear } \\
\text { or lingerie? }\end{array}$ & & & & & \\
\hline 3 & $\begin{array}{l}\text { Have you ever sent a nude } \\
\text { photo or video of yourself? }\end{array}$ & & & & & & \\
\hline 4 & $\begin{array}{l}\text { Have you ever sent a sexually } \\
\text { suggestive text message? }\end{array}$ & $\begin{array}{l}\text { Have you ever sent a text } \\
\text { message propositioning sexual } \\
\text { activity? }\end{array}$ & $\begin{array}{l}\text { Have you ever forwarded on or } \\
\text { showed others explicit } \\
\text { messages which were meant to } \\
\text { be kept private? }\end{array}$ & & & & \\
\hline
\end{tabular}

3. Emotional Promiscuity Scale (EPS)

\begin{tabular}{|c|c|c|c|c|c|c|}
\hline $\begin{array}{c}\text { Sr. } \\
\#\end{array}$ & Statements & $\begin{array}{l}\text { Strongly } \\
\text { Disagree }\end{array}$ & Disagree & $\begin{array}{l}\text { Neither Agree } \\
\text { Nor Disagree }\end{array}$ & Agree & $\begin{array}{l}\text { Strongly } \\
\text { Agree }\end{array}$ \\
\hline 1 & I fall in love easily. & & 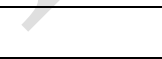 & & & \\
\hline 2 & $\begin{array}{l}\text { For me, romantic feelings take } \\
\text { a long time to develop. }\end{array}$ & & & & & \\
\hline 3 & $\begin{array}{l}\text { I feel romantic connections } \\
\text { right away. }\end{array}$ & & & & & \\
\hline 4 & $\begin{array}{l}\text { I love the feeling of falling in } \\
\text { love. }\end{array}$ & & & & & \\
\hline 5 & $\begin{array}{l}\text { I am not the type of person } \\
\text { who falls in love. }\end{array}$ & & & & & \\
\hline 6 & $\begin{array}{l}\text { I often feel romantic } \\
\text { connections to more than one } \\
\text { person at a time. }\end{array}$ & & & & & \\
\hline 7 & $\begin{array}{l}\text { I have been in love with more } \\
\text { than one person at the same } \\
\text { time. }\end{array}$ & & & & & \\
\hline 8 & I fall in love frequently. & & & & & \\
\hline 9 & $\begin{array}{l}\text { I tend to jump into } \\
\text { relationships. }\end{array}$ & & & & & \\
\hline & & A & B & $\mathrm{C}$ & $\mathrm{D}$ & $\mathrm{E}$ \\
\hline 10 & $\begin{array}{l}\text { During your entire life, how } \\
\text { many people have you fallen } \\
\text { in love with? }\end{array}$ & None & 1 & 2 & 3 & 4 or more \\
\hline
\end{tabular}


4. Sexual Sensation Seeking Scale (SSSS)

\begin{tabular}{|l|l|l|l|l|l|}
\hline $\begin{array}{l}\text { Sr. } \\
\#\end{array}$ & Statements & $\begin{array}{l}\text { Not at all } \\
\text { Like Me }\end{array}$ & $\begin{array}{l}\text { Slightly } \\
\text { Like Me }\end{array}$ & $\begin{array}{l}\text { Mainly } \\
\text { Like Me }\end{array}$ & $\begin{array}{l}\text { Very Much } \\
\text { Like Me }\end{array}$ \\
\hline 1 & I like wild sexual encounters. & & & & \\
\hline 2 & $\begin{array}{l}\text { The physical sensations are the most } \\
\text { important thing about having sex. }\end{array}$ & & & & \\
\hline 3 & $\begin{array}{l}\text { My sexual partners probably think that I am } \\
\text { a risk taker. }\end{array}$ & & & & \\
\hline 4 & $\begin{array}{l}\text { When it comes to sex, physical attraction is } \\
\text { more important to me than how well I know } \\
\text { the person. }\end{array}$ & & & & \\
\hline 5 & I enjoy the company of sensual people. & & & \\
\hline 6 & I enjoy watching X rated videos. & & & \\
\hline 7 & $\begin{array}{l}\text { I am interested in trying out new sexual } \\
\text { experiences. }\end{array}$ & & & & \\
\hline 8 & I feel like exploring my sexuality. & & & & \\
\hline 9 & $\begin{array}{l}\text { I like to have new and exciting sexual } \\
\text { experiences and sensations. }\end{array}$ & & & & \\
\hline 10 & $\begin{array}{l}\text { I enjoy the sensations of intercourse without } \\
\text { a condom. }\end{array}$ & & & & \\
\hline
\end{tabular}

